not alter, the fact that they are different. Taking a somewhat different case, Ferris admits (p. 279) the occurrence on African negroes of a louse that is typically strikingly different from Pediculus humanus as found on Europeans, but refuses (p. 271) to recognize $P$. humanus nigritarum because of the existence of intermediates. No doubt the lice of white men and of negroes have followed the example of their owners by interbreeding, but the supposed fact that there are no pure races of man does not prevent our recognizing the fact that races exist and that a negro and a white man are not exactly the same. I entirely agree with Prof. Ferris in his view that the problem of the lice of man and New World monkeys should be tackled genetically, but (because it is so much easier to put together pieces of information that have been wrongly segregated than to disentangle pieces that have been wrongly placed under one heading) I think it far better to recognize provisionally all named subspecies of Pediculus humanus for the existence of which a prima facie case can be made out on morphological grounds, quite regardless of any personal views as to whether genetical examination will result in their rejection or their retention.

There are a host-list of the Anoplura, a chapter on their distribution, and indexes of the lice themselves and of their hosts.

The book is undoubtedly by far the most important contribution to our knowledge of the Anoplura since the same author's "Contributions toward a Monograph of the Sucking Lice". It is, and will long remain, an absolute essential to any student of the group.

G. H. E. Hopkins

\section{AN AUSTRALIAN ABORIGINAL FERTILITY CULT}

Kunapipi

A Study of an Australian Aboriginal Religious Cult. By Ronald M. Berndt. Pp. xxxi+224+17 plates. (Melbourne: F. W. Cheshire Pty., Ltd.; London: Angus and Robertson, Ltd., 1951.) 39s. 6d.

THIS intensive study of a sacred cult that is found in north-eastern Australia shows that the aborigines, of this region at least, have a religious concept that far exceeds anything with which the Australian aborigines as a whole are usually credited. The author is well equipped to carry out research in these regions, as both he and his wife have lived with the natives in Arnhem Land and can speak the language - an essential qualification when ritual songs have to be transcribed and discussions on doctrine followed.

North-east Arnhem Land was selected, as it was an area subjected to the spread of native customs and rites from both west and south and was also likely to show the effects of long contact with Macassans and others who visited the coast to fish. The Kunapipi cult, which is widely diffused in the Northern Territories, has taken a strong hold in this region and is well defined, and its religious concepts are important and significant to the people there.

The cult is founded on the belief in the existence of a Great Mother, either a single or a dual personality, who is responsible for the constant fertility of human beings and others, and for the sequence of the seasons. The study of the cult involved more than observations of the rites performed on sacred ground, for ritual is an acting out of mythology which, in its turn, is recorded in detailed and elaborate song-cycles, which ensure the significance of the ritual. Therefore, the three aspects - ritual, mythology and song - must all be studied. This the author has done most fully and competently. The legends begin with the arrival in the land of the Fertility Mother, Kunapipi (or of two sisters), perpetually pregnant and releasing from her womb a stream of human beings-progenitors of the present natives, totemic beings and natural species. She did not act alone, for associated with her was the Rainbow Snake - the male element - an important aspect reflecting the part that the male plays in reproduction, and indicating that these natives are not ignorant of physiological paternity. But the Mother is the important figure, and women have had a far greater part to play in these ceremonies than is usually recorded; in fact, in legendary times they were directly responsible for them until the men stole the sacred objects while the women were away. But the women are still responsible for a series of ceremonies, and the aura of the Fertility Mother remains upon them to this day.

The author has also included a number of drawings made by the aborigines to illustrate the Kunapipi ritual. This is not the normal practice-they would enact a ceremony instead of drawing it-and the medium supplied (brown paper and crayons) was entirely foreign to an artist accustomed to working in ochres on bark with hair or root brushes. But the illustrations show how the artists adapted themselves surprisingly well and conveyed in a conventionalized style the major ritual points, which are explained by key plans. In addition, there are a number of songs from the relevant song-cycles sung. during the ceremonies and here translated with notes. The theme of the songs is primarily of the natural cycles of reproduction and fertility which is inherent in the ceremonies.

The book is also illustrated by interesting photographs of the ceremonies; but there does seem to be a certain lack of co-ordination between text, photographs, drawings and plans that makes the sequences difficult to follow and necessitates much turning of pages.

K. RISHBETH

\section{THE PROGRESS OF PHARMACOGNOSY}

\section{A Textbook of Pharmacognosy}

By T. C. Denston. Fifth edition. Pp. xviii +637. (London: Sir Isaac Pitman and Sons, Ltd., 1951.) 45s. net.

TOTWITHSTANDING the fact that the number of crude drugs in the British Pharmacopœia diminishes with each fresh edition, there is still an expanding field open to the pharmacognosist, as is shown by the need for the inclusion of fresh material in editions revised at fairly frequent intervals of text-books of pharmacognosy. Many old remedies discarded by the British Pharmacopœia still have a time-honoured place in pharmacy, and are retained in the British Pharmaceutical Codex, a valuable book of reference for medical practitioners and pharmacists. From time to time, one or other of 